\title{
NITRIDES AND CARBIDES IN 2101 LEAN DUPLEX STAINLESS STEEL
}

\author{
NITRIDI IN KARBIDI V LEAN DUPLEKSNEM NERJAVNEM \\ JEKLU 2101
}

\author{
Franc Tehovnik, Barbara Šetina Batič, Franci Vode, Simon Malej, Jaka Burja \\ Institute of Metals and Technology, Lepi pot 11, 1000 Ljubljana, Slovenia \\ franc.tehovnik@imt.si \\ Prejem rokopisa - received: 2018-07-13; sprejem za objavo - accepted for publication: 2018-10-18
}

doi:10.17222/mit.2018.145

\begin{abstract}
The 2101 lean duplex stainless steel (LDX) was designed mainly for lightweight constructions and as a more economical substitute for the dominating stainless-steel grades. Compared with other duplex stainless steels, the corrosion resistance and costs of processing the 2101 duplex stainless steel are usually worse, as the Ni and Mo contents are lower; it is compensated by higher $\mathrm{N}$ and $\mathrm{Mn}$ contents to stabilize the austenite. At lower test temperatures the precipitation of different phases was observed, so different annealing experiments were conducted to further investigate the occurrence of precipitation. As the composition of lean duplex stainless steel differs from that of conventional duplex stainless steels, a different aging behaviour is expected. The embrittlement of 2101 lean duplex stainless steel occurs at approximately $700{ }^{\circ} \mathrm{C}$ to $750{ }^{\circ} \mathrm{C}$, because of the precipitation of the deleterious $\mathrm{Cr}_{2} \mathrm{~N}$ and $\mathrm{M}_{23} \mathrm{C}_{6}$ at the $\delta / \gamma$ and $\delta / \delta$ interfaces, which begins after a few minutes of aging. These temperatures of the nitride precipitations are crucial to the cracking during the end of hot-working operations, which should stop at higher temperatures. The purpose of the research was to qualitatively analyse the phases in lean duplex stainless steel after thermal aging. Optical microscopy (OM), scanning electron microscopy (SEM) and electron-backscatter diffraction (EBSD) were used to investigate the structural stability and the chemical compositions of the phases.

Keywords: lean duplex stainless steel, isothermal annealing, precipitation, $\mathrm{Cr}_{2} \mathrm{~N}, \mathrm{Cr}_{23} \mathrm{C}_{6}$
\end{abstract}

Lean dupleks nerjavno jeklo LDX 2101 je bilo razvito predvsem za lahke konstrukcije in je ekonomičen nadomestek za večino nerjavnih jekel. V primerjavi z drugimi dupleksnimi nerjavnimi jekli je njegova odpornost proti koroziji slabša, saj sta vsebnosti $\mathrm{Ni}$ in Mo nižji, s tem pa so nižji tudi stroški izdelave. Stabilizacijo austenita kompenziramo z višjo vsebnostjo N in Mn. Avtorji raziskave so ugotavljali izločanje različnih faz pri različnih pogojih žarjenja in nižjih temperaturah preizkušanja. Ker se sestava preiskovanega nerjavnega jekla razlikuje od sestave klasičnih dupleks nerjavnih jekel, se to jeklo med postopki žarjenja obnaša drugače. Krhkost preiskovanega nerjavnega jekla se pojavi med $700{ }^{\circ} \mathrm{C}$ do $750{ }^{\circ} \mathrm{C}$ zaradi izločanja $\mathrm{Cr}_{2} \mathrm{~N}_{\text {in }} \mathrm{M}_{23} \mathrm{C}_{6}$ na mejah delta feritnih kristalnih zrn $(\delta / \delta)$ in mejah zrn delta ferita in austenita $(\delta / \gamma)$. Izločanje se prične že po nekaj minutah žarjenja. Namen raziskave je bila kvalitativna analiza faz v preiskovanem dupleks nerjavnem jeklu med temperaturnim žarjenjem. Za raziskovanje strukturne stabilnosti in kemijske sestave faz so avtorji uporabili optično mikroskopijo (OM), vrstično elektronsko mikroskopijo (SEM) in uklon povratno sipanih elektronov (EBSD).

Ključne besede: lean dupleks nerjavno jeklo, izotermno žarjenje, izločanje, $\mathrm{Cr}_{2} \mathrm{~N}, \mathrm{Cr}_{23} \mathrm{C}_{6}$

\section{INTRODUCTION}

The 2101 lean duplex stainless steel (LDX) was designed mainly for lightweight constructions and as a more economical substitute for the dominating stainless-steel grades. LDX 2101 was developed with a low content of nickel in order to reduce and stabilize the costs. The low nickel content is compensated by an increased amount of gamma-stabilizing manganese and nitrogen to ensure a balanced microstructure with approximately equal amounts of ferrite and austenite. The strength of this material is comparable to DSS 2205 and the corrosion properties are generally better than for austenitic AISI 304. ${ }^{1-4}$

Knowledge of the secondary-phase formation is necessary for an exploitation of the LDX, mainly in two practical situations:

- cooling from high temperatures, as in the quenching treatment after solution annealing or after welding operations,
- during long holding times at high temperatures, for instance, during service.

On the other hand, LDX stainless steels have been found to be affected by nitride and carbide formation. ${ }^{5}$ In any case, all duplex stainless steels are sensitive to the precipitation of nitrides, as they contain significant percentages of nitrogen. ${ }^{6-7}$ Nitride formation is strictly related to the variation of temperature and nitrogen solubility in ferrite, which increases at high temperature, thus bringing ferrite in supersaturated solid-solution conditions at room temperature. In the solution-annealed condition, these alloys retain almost all of the nitrogen in the austenite. The solubility difference of the nitrogen in the ferrite and the austenite is particularly high at low temperatures. ${ }^{8}$ In LDX stainless steel, the $\gamma^{\prime}$ secondary austenite can be observed at the $\gamma / \delta$ interfaces, and the co-precipitation mechanisms $\delta \rightarrow \mathrm{M}_{23} \mathrm{C}_{6}+\gamma^{\prime}$ and $\delta \rightarrow$ $\mathrm{Cr}_{2} \mathrm{~N}+\gamma^{\prime}$ are assumed. ${ }^{9}$ 
Table 1: Chemical composition LDX 2101 in mass fractions (w/\%)

\begin{tabular}{|c|c|c|c|c|c|c|c|c|c|c|c|}
\hline $\mathrm{C}$ & $\mathrm{Si}$ & $\mathrm{Mn}$ & $\mathrm{P}$ & $\mathrm{S}$ & $\mathrm{Cr}$ & $\mathrm{Ni}$ & $\mathrm{Cu}$ & $\mathrm{Mo}$ & $\mathrm{Al}$ & $\mathrm{N}$ & $\mathrm{Fe}$ \\
\hline 0.03 & 0.68 & 4.9 & 0.024 & 0.001 & 21.4 & 1.46 & 0.27 & 0.32 & 0.015 & 0.226 & $\mathrm{Bal}$. \\
\hline
\end{tabular}

Table 2: Mechanical properties of the investigated lean duplex stainless steel in solution-annealed condition at room temperature

\begin{tabular}{|c|c|c|c|c|c|}
\hline Direction of rolling & $\begin{array}{c}\text { Proof strength } R_{\mathrm{p} 02} \\
(\mathrm{MPa})\end{array}$ & $\begin{array}{c}\text { Tensile strength } R_{\mathrm{m}} \\
(\mathrm{MPa})\end{array}$ & Elongation $A(\%)$ & $\begin{array}{c}\text { Reduction of area } \\
(\%) Z\end{array}$ & $\begin{array}{c}\text { Impact toughness } \\
\text { average }(\mathrm{KV})\end{array}$ \\
\hline Longitudinal & 464 & 696 & 45 & 69 & 291 \\
\hline
\end{tabular}

The mechanisms of precipitation and phase transformation can be described as follows. ${ }^{10,11}$ Both carbides and nitrides precipitate on the $\gamma / \delta$ phase boundary and cause cracking (embrittlement) during hot deformation. ${ }^{9}$ The $\mathrm{M}_{23} \mathrm{C}_{6}$ exhibits a specific triangular morphology, while the $\mathrm{Cr}_{2} \mathrm{~N}$ exhibits a rod-like morphology. The rapid precipitation of $\mathrm{Cr}_{2} \mathrm{~N}$ and $\gamma^{\prime}$ occurs after a few minutes of ageing. $\mathrm{Cr}_{2} \mathrm{~N}$ and $\gamma^{\prime}$ grow together in the $\delta$ phase until the diffusion of the heavy nitride-forming elements, such as $\mathrm{Cr}$, Mo and $\mathrm{V}$, limits the $\mathrm{Cr}_{2} \mathrm{~N}$ growth and allows the $\gamma$ ' to grow alone. In the vicinity of the $\gamma / \delta$ interphase boundary, the $\mathrm{Cr}$ depletion is located first in the $\delta$ because $\mathrm{Cr}$ diffusion is faster in $\delta$ than in $\gamma$. In contrast, at the $\delta / \delta$ interfaces only $\mathrm{Cr}_{2} \mathrm{~N}$ precipitates and no $\gamma^{\prime}$ is observed along the $\delta / \delta$ interface. The precipitation of $\mathrm{Cr}_{2} \mathrm{~N}$ occurs at the $\gamma / \gamma$ interface after $10 \mathrm{~h}$ of ageing, as the diffusion kinetics are slower in the austenite.

Due to the increased content of nitrogen in 2201, the precipitation of $\mathrm{Cr}_{2} \mathrm{~N}$-type nitrides increased in the temperature range from $700{ }^{\circ} \mathrm{C}$ to $900{ }^{\circ} \mathrm{C}$. It is accepted that the embrittlement nose of LDX is approximately from $650{ }^{\circ} \mathrm{C}$ to $750{ }^{\circ} \mathrm{C}$, because of the $\mathrm{Cr}_{2} \mathrm{~N}$ and $\mathrm{M}_{23} \mathrm{C}_{6}$ precipitation at the $\gamma / \delta$ and $\delta / \delta$ interfaces after a few minutes of aging. ${ }^{6} 10-12$ The precipitation of nitrides and carbides was studied in the temperature range where hot rolling usually ends for most steels. Precipitates formed at the upper temperatures in the embrittlement nose (700-900 ${ }^{\circ} \mathrm{C}$ for $30 \mathrm{~min}$ and $120 \mathrm{~min}$ ) were studied by qualitative phase analysis.

\section{EXPERIMENTAL PART}

The lean duplex stainless-steel grade LDX 2101 with the chemical composition given in Table 1 was used in the experimental work. The specimens were cut from 20-mm-thick hot-rolled and solution-annealed plate. Table 2 shows the mechanical properties of the investigated steel. The initial microstructure is presented in Figure 1. At the $1100{ }^{\circ} \mathrm{C}$ annealing temperature both phases have an almost fully recrystallized microstructure.

Cylindrical specimens with a diameter $4 \mathrm{~mm}$ and a length of $10 \mathrm{~mm}$ were machined from flat specimens. Hot-ageing tests were performed on a TA Instruments dilatometer DIL805A/D, due to its good temperature and atmosphere control. The specimens were isothermally annealed at different temperatures from $700{ }^{\circ} \mathrm{C}$ to
$900{ }^{\circ} \mathrm{C}$ in $50{ }^{\circ} \mathrm{C}$ steps under vacuum $\left(5 \cdot 10^{-4} \mathrm{mbar}\right)$. The specimens were heated at a rate of $10 \mathrm{~K} / \mathrm{s}$. The kinetics of the intermetallic phase precipitation was investigated by annealing for $30 \mathrm{~min}$ and $120 \mathrm{~min}$ and then quenching at the rate of $50 \mathrm{~K} / \mathrm{s}$. The samples were etched with a solution of $30 \mathrm{~g} \mathrm{KOH}, 30 \mathrm{~g} \mathrm{~K}_{3} \mathrm{Fe}(\mathrm{CN})_{6}$ and $100 \mathrm{~mL}$ distilled water. The etching causes the phases in the microstructure to colour differently: the $\delta$-ferrite is dark and the $\gamma$-austenite is light. The specimens were investigated by optical microscopy and scanning electron microscopy (SEM) with energy-dispersive X-ray spectroscopy (EDS) and the electron-backscatter diffraction (EBSD) technique. A Jeol JSM 6500-F field-emission scanning electron microscope, equipped with an Oxford EDS system and a Nordlys II EBSD detector was used
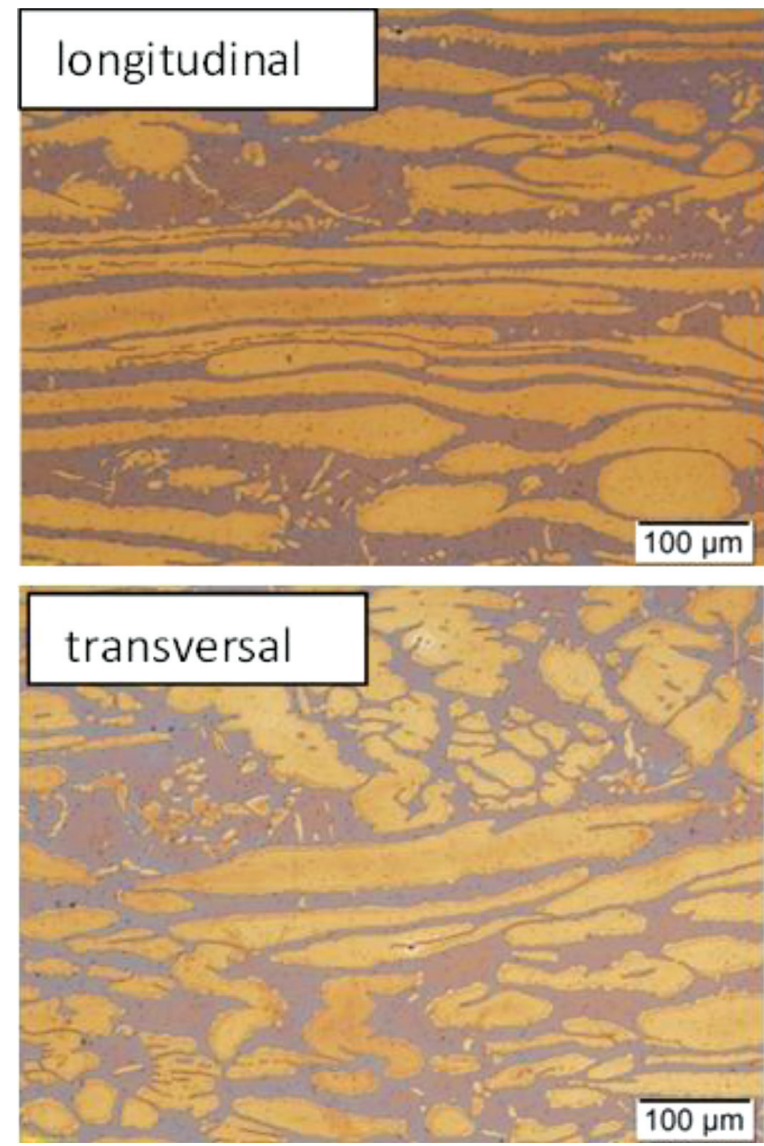

Figure 1: Initial microstructure of LDX 2101 duplex stainless steel, with austenite (light) and ferrite (dark) in the as-rolled longitudinal and transversal directions 
for the electron microscopy. Post-processing of the EBSD data was performed with Channel 5 software.

\section{RESULTS AND DISCUSSION}

The equilibrium phase composition for LDX 2101 was calculated using the Thermo-Calc TCFE8 database. The results are presented in Figure 2. As shown in Figure 2, the equilibrium phase diagram calculated for the experimental LDX 2101 indicates that only $\delta$-ferrite and $\gamma$-austenite are stable above $960{ }^{\circ} \mathrm{C}$. The ferrite and austenite contents are almost equivalent in the temperature range between $1100{ }^{\circ} \mathrm{C}$ and $1150{ }^{\circ} \mathrm{C}$. The secondary phases are thermodynamically stable at lower temperatures, the nitrides below $960{ }^{\circ} \mathrm{C}$, the carbides below $850{ }^{\circ} \mathrm{C}$ and the $\sigma$-phase below $750{ }^{\circ} \mathrm{C}$.

Figure 3 shows a series of optical micrographs of the specimens aged at different temperatures for $30 \mathrm{~min}$ and $120 \mathrm{~min}$. The fine precipitates formed only between the austenite island and the ferrite matrix $(\delta / \gamma)$ in the samples aged at $700{ }^{\circ} \mathrm{C}$ for $30 \mathrm{~min}$. The fine precipitates were also found at $750{ }^{\circ} \mathrm{C}$ for $30 \mathrm{~min}$ at the $\delta / \gamma$ and $\delta / \delta$ the grain boundaries. The size and the amount of precipitates increased after $120 \mathrm{~min}$ of ageing in the temperature range from $750{ }^{\circ} \mathrm{C}$ to $850{ }^{\circ} \mathrm{C}$. The nitrides formed along the $\delta / \gamma$ interface grew towards the ferrite, and the secondary austenite surrounding precipitate started to form. It is clear that the $\delta / \gamma$ interface moved away from the precipitate particles and grown into the ferrite phase, leaving the precipitates behind along the original interfaces.

The SEM image of the microstructure and the EDS analysis are shown in Figure 4, where the sample was aged at $800{ }^{\circ} \mathrm{C}$ for $120 \mathrm{~min}$. Our results are in agreement with Liljas et al. ${ }^{1}$ and Fang et al. ${ }^{13}$ The EDS analysis revealed that the precipitates at the $\delta / \gamma$ and $\delta / \delta$ interfaces had high chromium contents. The region near the precipitates showed a lower chromium content compared to the ferrite phase, the austenite phase and the preci-

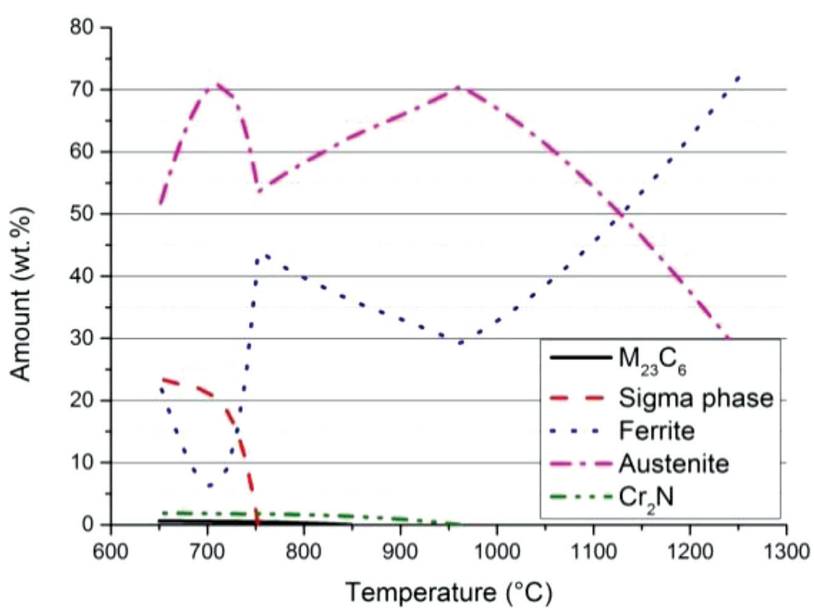

Figure 2: Equilibrium phase diagram calculated using Thermo-Calc for the lean duplex stainless steel LDX 2101
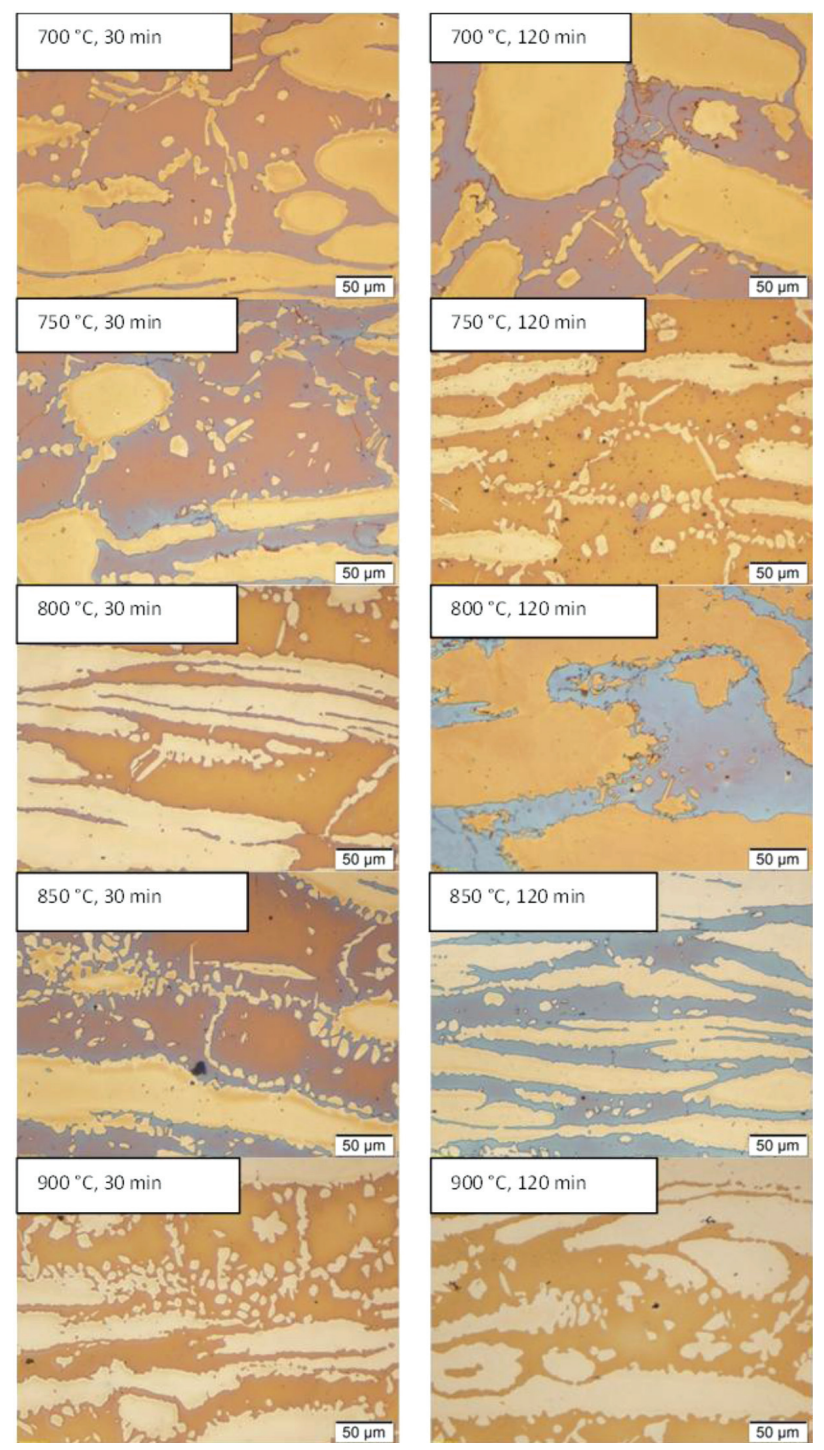

Figure 3: Optical micrographs for the microstructures formed during isothermal annealing after $30 \mathrm{~min}$ and $120 \mathrm{~min}$ at different temperatures

pitates. This low chromium region was identified as secondary austenite $\left(\gamma^{\prime}\right)$. In the vicinity of the $\delta / \gamma$ interface, the $\mathrm{Cr}$ depletion first occurs in $\delta$, because $\mathrm{Cr}$ diffusion is faster in ferrite than in austenite. The interfaces between the austenite islands and the ferrite grain boundaries are believed to be the preferential nucleation sites for the heterogeneous precipitation of $\mathrm{Cr}_{2} \mathrm{~N}$-type nitrides and $\mathrm{M}_{23} \mathrm{C}_{6}$ type carbides. ${ }^{14-16}$ The $\delta$ transformation at the $\delta / \gamma$ interface is described as (1):

$$
\delta=\gamma^{\prime}+\mathrm{Cr}_{2} \mathrm{~N}+\mathrm{M}_{23} \mathrm{C}_{6}
$$

Compared to the normal austenite, secondary austenite is enriched in nickel and manganese, and depleted in chromium. The SEM image and the EDS analysis of the $\mathrm{Cr}_{2} \mathrm{~N}$ are shown in Figure 5. These $\mathrm{Cr}_{2} \mathrm{~N}$ precipitates have a high concentration of $\mathrm{Cr}$ and $\mathrm{N}$ and contain $\mathrm{Fe}, \mathrm{Ni}$ and $\mathrm{Mn}$. The precipitation of $\mathrm{Cr}_{2} \mathrm{~N}$ is often accompanied by the formation of secondary austenite due to a de- 


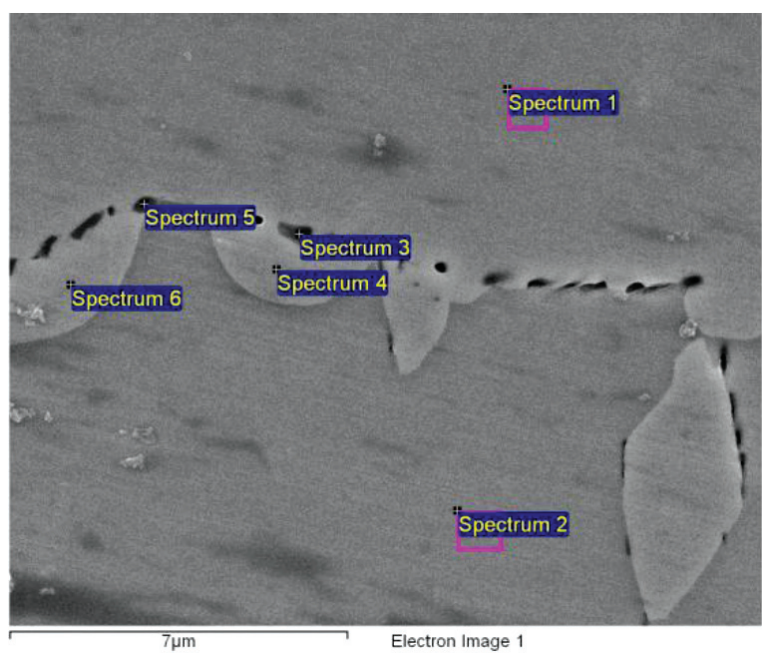

Figure 4: SEM micrograph and EDS analysis for the microstructure after isothermal annealing at $800{ }^{\circ} \mathrm{C}$ for $120 \mathrm{~min}$

\begin{tabular}{|c|c|c|c|c|c|c|}
\hline \multicolumn{2}{|c|}{ Spectrum $(w / \%)$} & $\mathrm{Si}$ & $\mathrm{Cr}$ & $\mathrm{Mn}$ & $\mathrm{Fe}$ & $\mathrm{Ni}$ \\
\hline Spectrum 1 & $\gamma$ & 0.8 & 20.9 & 5.4 & 71.1 & 1.8 \\
\hline Spectrum 2 & $\delta$ & 0.9 & 22.4 & 5.5 & 69.9 & 1.4 \\
\hline Spectrum 3 & $\mathrm{Cr}_{2} \mathrm{~N}$ & 0.3 & 26.0 & 5.7 & 66.3 & 1.6 \\
\hline Spectrum 4 & $\gamma^{\prime}$ & 0.6 & 18.7 & 5.4 & 72.9 & 2.5 \\
\hline Spectrum 5 & $\mathrm{Cr}_{2} \mathrm{~N}$ & 0.6 & 24.5 & 5.9 & 66.9 & 2.0 \\
\hline Spectrum 6 & $\gamma$ & 0.7 & 18.5 & 5.8 & 72.5 & 2.5 \\
\hline
\end{tabular}

crease in the amount of $\mathrm{Cr}$ in the ferrite. Because $\alpha$ stabilizer elements are also $\sigma$-phase stabilizers, the $\sigma$ phase precipitates in the $\delta$ once the nitrogen, carbon and nickel contents in the $\delta$ are low enough. ${ }^{17-19}$ In the investigated LDX 2101 duplex stainless steel, this precipitation does not occur after $120 \mathrm{~min}$ of ageing. The kinetics of the $\sigma$-phase precipitation is expected to be more sluggish than in standard (SAF 2205) and super

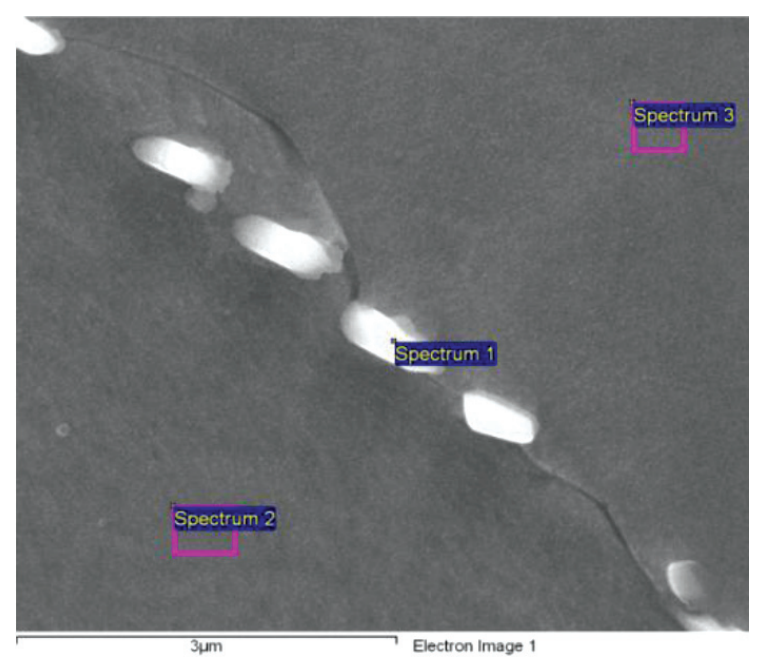

Figure 5: SEM micrograph and EDS analysis of austenite, ferrite and $\mathrm{Cr}_{2} \mathrm{~N}$ after isothermal annealing at $800{ }^{\circ} \mathrm{C}$ for $120 \mathrm{~min}$

\begin{tabular}{|c|c|c|c|c|c|c|c|c|c|}
\hline \multicolumn{2}{|c|}{ Spectrum $(w / \%)$} & $\mathrm{N}$ & $\mathrm{Si}$ & $\mathrm{V}$ & $\mathrm{Cr}$ & $\mathrm{Mn}$ & $\mathrm{Fe}$ & $\mathrm{Ni}$ & $\mathrm{Mo}$ \\
\hline Spectrum 1 & $\mathrm{Cr}_{2} \mathrm{~N}$ & 13.4 & 0.5 & 1.5 & 50.3 & 3.7 & 30.2 & 0.4 & 0.0 \\
\hline Spectrum 2 & $\gamma$ & 0.0 & 0.8 & 0.0 & 20.5 & 5.5 & 69.9 & 1.5 & 0.5 \\
\hline Spectrum 3 & $\delta$ & 0.0 & 1.0 & 0.0 & 23.0 & 4.7 & 69.7 & 1.1 & 0.6 \\
\hline
\end{tabular}

duplex stainless steel (SAF 2507) due to the lower $\mathrm{Cr}$ and Mo contents, ${ }^{20-21}$ and the $\sigma$-phase is generally observed after several tens of hours of aging at $700{ }^{\circ} \mathrm{C}$. The examination of LDX 2101 aged for $120 \mathrm{~min}$ $\left(800{ }^{\circ} \mathrm{C}\right)$ revealed that the precipitates are located at the initial $\gamma / \delta, \gamma / \gamma, \delta / \delta$ interface and in the ferrite interior (Figure 5).

Nitrides $\left(\mathrm{Cr}_{2} \mathrm{~N}\right)$ and carbides $\left(\mathrm{M}_{23} \mathrm{C}_{6}\right)$ are observed on the grain $\gamma / \gamma$ boundaries, at the triple-junction points and on the twin boundaries. Intergranular precipitation in the austenite does not occur after two hours of aging. To confirm the presence of the different phases, we performed spot EBSD analysis for each representative phase. As seen in Figure 6, the phases give distinctively different Kikuchi patterns and can be indexed as ferrite, austenite, $\mathrm{Cr}_{2} \mathrm{~N}$ and $\mathrm{M}_{23} \mathrm{C}_{6}$. The crystal structures of the phases are given in Table 3. The austenite phase and the carbide phase have the same crystal structure (FCC), but the lattice parameter of the carbide phase is approximately three times the lattice parameter of the austenite phase. The $\mathrm{Cr}_{2} \mathrm{~N}$ phase has a hexagonal structure.

Table 3: List of phases investigated in the lean duplex stainless steel using EBSD

\begin{tabular}{|c|c|c|}
\hline Phase & Crystal structure & Lattice parameters (nm) \\
\hline Ferrite & $\begin{array}{c}\text { Body Centred Cubic } \\
\text { (BCC) }\end{array}$ & $a=0.287$ \\
\hline Austenite & $\begin{array}{c}\text { Face Centred Cubic } \\
\text { (FCC) }\end{array}$ & $a=0.366$ \\
\hline $\mathrm{M}_{23} \mathrm{C}_{6}$ & $\begin{array}{c}\text { Face Centred Cubic } \\
\text { (FCC) }\end{array}$ & $a=1.056$ \\
\hline $\mathrm{Cr}_{2} \mathrm{~N}$ & Hexagonal & $a=0.481, c=0.448$ \\
\hline
\end{tabular}

A detailed analysis showed that the carbides are fine particles between $\gamma$ and $\gamma^{\prime}$, having the same crystallographic structure as the austenite $\gamma$, and cube-to-cube orientation with the $\gamma$-phase. The co-precipitation of $\mathrm{M}_{23} \mathrm{C}_{6}$ and $\gamma^{\prime}$ along the $\gamma-\delta$ boundaries is thermodynamically favourable, as $\mathrm{M}_{23} \mathrm{C}_{6}$ is enriched in chromium, whereas the $\gamma^{\prime}$ is depleted. Particles with a hexagonal structure along the $\gamma-\gamma^{\prime}, \gamma-\delta$ and $\gamma-\delta$ grain boundaries were identified as chromium nitrides. The ferritic regions are characterized by the high diffusivity and low

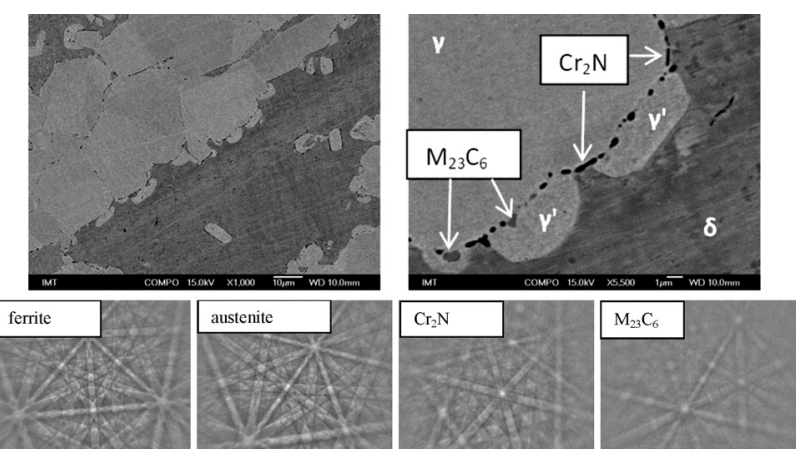

Figure 6: Electron-backscatter image after isothermal ageing at $800{ }^{\circ} \mathrm{C}$ for 120 min with marked phases and the corresponding Kikuchi patterns 

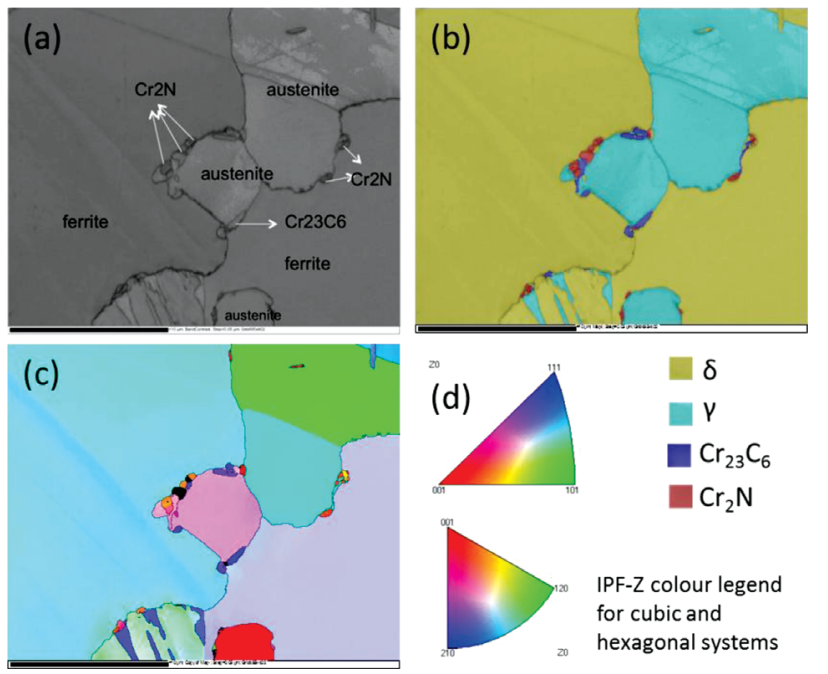

Figure 7: EBSD mapping of specimen after isothermal ageing at 800 ${ }^{\circ} \mathrm{C}$ for $120 \mathrm{~min}$, a) band-contrast map, reproducing the microstructure, b) identification of phases, overlaid with band-contrast map, c) IPF-Z colour-coded map, showing the orientations of the individual particles, d) legend for the IPF-Z colour coding

solubility of nitrogen. Both these factors encourage nitride precipitation from the ferrite.

Figure 7 shows higher-magnification EBSD images after isothermal ageing at $800{ }^{\circ} \mathrm{C}$ for $120 \mathrm{~min}$. Figure 7a shows the band-contrast map, which reproduces the microstructure of the specimens. As observed, the microstructure consisted of a mixture of ferrite, austenite and a small amount of $\mathrm{M}_{23} \mathrm{C}_{6}$ and $\mathrm{Cr}_{2} \mathrm{~N}$ along the boundaries. The matrix consists of ferrite with austenitic islands. Figure $\mathbf{7 b}$ is a representation of the phases, where we can clearly observe the presence of four different phases. Figure 7c shows the orientation of the individual particles and Figure 7d shows a legend for the IPF-Z colour coding.

A higher-resolution map (with a step size of $50 \mathrm{~nm}$ ) allowed clear observations of the newly formed microstructure. The austenite grain at the interphase had convoluted morphologies, with newly formed secondary austenite protruding from the primary austenite islands

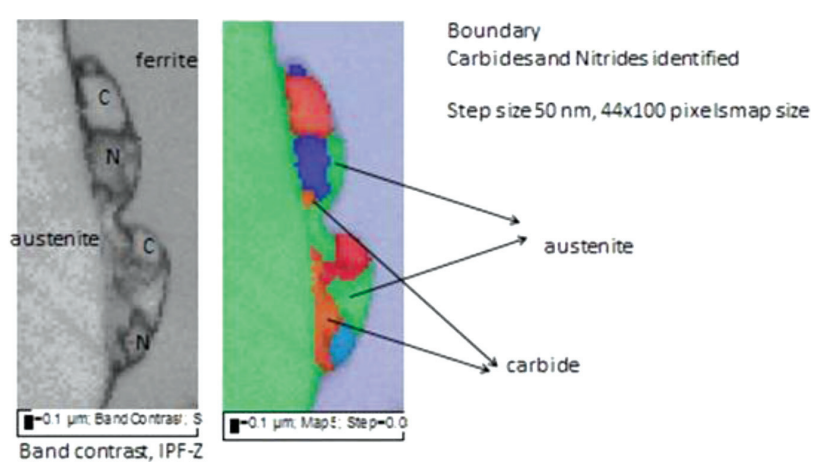

Figure 8: High-resolution EBSD mapping (step size of $50 \mathrm{~nm}$ ) of the boundary between austenite and ferrite. Carbide and nitride precipitates are visible, a) band-contrast map, b) IPF-Z colour-coded map, showing the protruding of the austenite phase (green orientation) and individual carbide and nitride particles
(Figure 8). The secondary austenite seemed to have developed through grain growth from the ferrite, indicated by the white dashed line in Figure 8, showing the approximate position of the initial $\delta / \gamma$ phase boundary. From the results of the EDS and EBSD analyses in this paper, the precipitates were confirmed to the mainly $\mathrm{Cr}_{2} \mathrm{~N}$ and $\mathrm{Cr}_{23} \mathrm{C}_{6}$, instead of the sigma phase. These are two main reasons for $\mathrm{Cr}_{2} \mathrm{~N}$ becoming the critical precipitation in DSS 2101, instead of the sigma phase. Molybdenum controls the $\sigma$-phase formation. The content of molybdenum is only 0.32 w/\% in DSS 2101 . The high nitrogen content significantly increases the precipitation trend of the $\mathrm{Cr}_{2} \mathrm{~N}$-type nitrides and also retards the sigma-phase formation. The results reveal rapid $\mathrm{Cr}_{2} \mathrm{~N}$ precipitation during the aging of the DSS $2101 .{ }^{9}$

\section{CONCLUSIONS}

Isothermal ageing treatments were carried out over the temperature range from $700{ }^{\circ} \mathrm{C}$ to $900{ }^{\circ} \mathrm{C}$ for $30 \mathrm{~min}$ and $120 \mathrm{~min}$. The conclusions are as follows:

- The equilibrium phase diagram calculated using Thermo-Calc software for the experimental LDX 2101 indicated that $\delta$-ferrite and $\gamma$-austenite are stable above $960{ }^{\circ} \mathrm{C}$. The secondary phases are thermodynamically stable at lower temperatures, the nitrides below $960{ }^{\circ} \mathrm{C}$, the carbides below $850{ }^{\circ} \mathrm{C}$ and the $\sigma$-phase below $750{ }^{\circ} \mathrm{C}$.

- The temperature range from $700{ }^{\circ} \mathrm{C}$ to $900{ }^{\circ} \mathrm{C}$ is problematic for the formation of harmful precipitates. The $\mathrm{Cr}_{2} \mathrm{~N}$-type nitrides and a small amount of $\mathrm{M}_{23} \mathrm{C}_{6}$-type carbides were formed at the grain boundaries, thus weakening them. The nitrides formed along the $\delta / \gamma$ interface grew towards ferrite, and the secondary austenite surrounding the precipitates started to form. These temperatures of nitride precipitations are crucial for cracking during the end of hot-working operations, which should stop at higher temperatures.

- The newly formed secondary austenite $\gamma^{\prime}$ is poorer in chromium and enriched in nickel compared to the primary austenite.

- $\mathrm{M}_{23} \mathrm{C}_{6}$ has a triangular morphology, unlike $\mathrm{Cr}_{2} \mathrm{~N}$, which has a rod-like morphology and grows continuously with time.

- The LDX 2101 duplex stainless steel is resistant to the formation of the sigma phase in the $700-900{ }^{\circ} \mathrm{C}$ range for up to $120 \mathrm{~min}$, mainly due to low Mo and high N. No evidence of sigma-phase precipitation was found, and the annealing time of 120 min was not long enough.

\section{REFERENCES}

${ }^{1}$ M. Liljas, P. Johansson, H. P. Liu and C.O.A. Olson, Development of a lean duplex stainless steel, Steel. Res. Int., 79 (2008) 6, 466-473, doi:10.1002/srin.200806154 


\section{F. TEHOVNIK et al.: NITRIDES AND CARBIDES IN 2101 LEAN DUPLEX STAINLESS STEEL}

${ }^{2}$ D. N. Zou, K. Wu, Y. Han, W. Zhang, B. Cheng, G. J. Qiao, Deformation characteristic and prediction of flow stress for as-cast $21 \mathrm{Cr}$ economical duplex stainless steel under hot compression, Mater. Des., 51 (2013), 975-982, doi:10.1016/j.matdes.2013.04.065

${ }^{3}$ J. Pilhagen, R. Sandstrom, Influence of nickel on the toughness of lean duplex stainless steel welds, Mater. Sci. Eng. A. 602 (2014), 49-57, doi: org/10.1016/j.msea.2014.01.093

${ }^{4}$ S. M. Wessman, S. Hertzman, R. Pettersson, R. Lagneborg, M Liljas, On the effect of nickel substitution in duplex stainless steel, Mater. Sci. Tech., 24 (2008) 3, 348-355

${ }^{5}$ I. Calliari, M. Pellizzari, M. Zanellato, E. Ramous, The phase stability in $\mathrm{Cr}-\mathrm{Ni}$ and $\mathrm{Cr}-\mathrm{Mn}$ duplex stainless steels, J. Mater. Sci., 46, (2011), 6916-6924, doi:10.1007/s10853-011-5657-7

${ }^{6}$ M. Breda, M. Pellizzari, M. Frigo, $\sigma$-phase in lean duplex stainless steel sheets, Acta. Metall. Sin. 28 (2015), (3) 331-337, doi:10.1007/s40195-014-0201-9

${ }^{7}$ M. Knyazeva, M. Pohl, Duplex steels: Part I: Genesis, formation, structure, Metallogr. Microstruct. Anal., 2 (2013), 113-121, doi:10.1007/s13632-013-0066-8

${ }^{8}$ J. Charles, P. Chemelle, The history of duplex developments, nowadays DSS properties and duplex market future trends: Duplex stainless steel, Conference Proceedings, Beaune, France, 2010

${ }^{9}$ W. Zhang, L. Z. Jiang, J. Q. Gao, H. M. Song, J. C. Hu, Study of precipitation in 2101 duplex stainless steel, Mater. Sci. Tech., 26 (2010) 5, 515-521, doi:10.11.79/174328409X405689

${ }^{10}$ J. Maetz, S. Cazottes, C. Verdu, X. Kleber, Precipitation and phase transformations in 2101 lean duplex stainless steel during isothermal aging, Metall. Mater. Trans. A, 47A, (2016), 2016-2239, doi:10.1007/s11661-015-3215-7

${ }^{11}$ W. Zhang, L. Z. Jiang, J. C. Hu and H. M. Song, Effect of ageing on precipitation and impact energy of 2101 economical duplex stainless steel, Mater. Charact., 60 (2009), 50-55, doi:10.1016/j.matchar. 2008.07.002
${ }^{12}$ I. Calliari, M. Pellizzari, M. Zanellato, E. Ramous, The phase stability in Cr-Ni and Cr-Mn duplex stainless steels, J. Mater. Sci., 46, (2011), 6916-6924, doi:10.1007/s10853-011-5657-7

${ }^{13}$ Y. L. Fang, Z. Y. Liu, W. Y. Xue, H. M. Song, 1. Z. Jiang, Precipitation of secondary phases in lean duplex stainless steel 2101 during isothermal ageing, ISIJ Int., 50, 2, (2010), 286-293

${ }^{14}$ A. J. Ramirez, J. C. Lippold, S. D. Brandi, The relationship between chromium nitride and secondary precipitation in duplex stainless steels, Metall. Mater. Trans. A, 34 (2003), 1575-1597

${ }^{15}$ T. H. Chen, J. R Yang, Microstructural characterization of simulated heat affected zone in a nitrogen-containing 2205 duplex stainless steel, Mater. Sci. Eng. A, 338 (2002), 166-181, doi:S0921-5093(02) 00065-5

${ }^{16}$ T. Amadou, A. Ben Rhouma, H. Sidhom, C. Braham, J. Ledion, Influence of thermal aging on the reactivity of duplex stainless steel surfaces, Metall. Mater. Trans. A, 31 (2000), 2015-2024

${ }^{17}$ T. H.Lee, C. S. Oh, C. G. Lee, S. J. Kim, S. Tanaki, Precipitation of r-phase in high-nitrogen austenitic $18 \mathrm{Cr}-18 \mathrm{Mn}-2 \mathrm{Mo}-0.9 \mathrm{~N}$ stainless steel during isothermal aging, Scripta Mater., 50, (2004),1325-1328, doi:10.1016/j.scriptamat.2004.02.013

${ }^{18}$ A. F. Padilha, P. R. Rios, Decomposition of austenite in austenitic stainless steels, ISIJ Int., 42, (2002), 325-337

${ }^{19}$ C. S. Huang, C. S. Shih, Effect of nitrogen and high temperature aging on $\sigma$ phase precipitation of duplex stainless steel, Mater. Sci. Eng. A, 402 (2005), 66-75, doi: 10.1016/j.msea.2005.03.111

${ }^{20}$ F. Tehovnik, B. Žužek, J. Burja, Hot tensile testing of SAF 2205 duplex stainless steel, Mater. Tehnol., 50, 6, (2016), 989-993, doi:10.17222/mit.2016.242

${ }^{21}$ F. Tehovnik, B. Arzenšek, B. Arh, D. Skobir, B. Pirnar, B. Žužek, Microstructure evolution in SAF 2507 super duplex stainless steel, Mater. Tehnol., 45 (2011) 4, 339-345 